Thordis Reimer

ORCID: https://orcid.org/0000-0001-9457-6331

Universität Hamburg ${ }^{1}$

Birgit Pfau-Effinger

ORCID: https://orcid.org/0000-0001-8915-8397

Universität Hamburg 2

\title{
Different types of parental leave use by German fathers and their engagement in childcare in subsequent years
}

\begin{abstract}
This paper examines the relationship between different aspects of the parental leave use by German fathers and their subsequent engagement in childcare. The relationship between the use of parental leave by fathers and their time spent on childcare on weekdays in subsequent years is broken down by three different details to parental leave use (duration, timing and partner's employment status during parental leave). It also examines whether fathers who take parental leave provide more childcare even before they take the parental leave compared to fathers who do not use parental leave. The study is based on German panel data and applies group comparisons with t-test and

1 Correspondence: Thordis Reimer, Allende Platz 1, 20146 Hamburg, author's email address: thordis.reimer@uni-hamburg.de

2 Correspondence: Birgit Pfau-Effinger, Allende Platz 1, 20146 Hamburg, author's email address: pfau-effinger@uni-hamburg.de
\end{abstract}


difference-in-differences analysis. The results demonstrate that if fathers take more than two months' leave or if they take parental leave alone they spend on average more time on childcare after the leave period than fathers not using parental leave. The differences to fathers with no leave use are strongest for fathers who take advantage of leave alone, i.e. when their partner is working. We also discover that on average, fathers on leave (alone) are not inclined to more childcare before the parental leave period compared to fathers not using parental leave. Based on identity theory and the undoing gender framework, the cautious interpretation of the results is that fathers who are on leave for more than two months or were on leave alone experience a shift in their commitment to childcare during the leave period.

Key words: fathers, parental leave, childcare, leave alone

\section{Introduction}

In the mid-2000s, a new family policy instrument was introduced in Germany, which aims at equal sharing of employment and childcare between women and men. A key element of the programme was the new parental leave entitlements under the heading "sustainable family policy", which provided generous benefits for a period of twelve months and two additional bonus months exclusively for the second parent. Together, these new entitlements to parental leave should activate fathers' participation in childcare (Ehlert \& Rüling, 2008; Reimer, 2013), as they are considered to be the key conditions for fathers to take parental leave (Eydal \& Gislason, 2015). Since the introduction of the new law on parental leave 2007, the take-up of parental leave by fathers has increased steadily. When fathers take parental leave, they currently often take only the two exclusive bonus months (Reimer \& Andernach, 2015), and there is still a gender gap in the use of parental leave

It is assumed that the use of parental leave by fathers also increases their participation in childcare after leave (O'Brien, 2009) and thus contributes to greater gender equality in families beyond leave. Research shows that there is a link between parental leave use of fathers and their subsequent participation in childcare (Almqvist \& Duvander, 2014; Escot, Fernández-Cornejo \& Poza, 2014; Haas \& Hwang, 2008; Huerta et al., 2013; Meil, 2013; Nepomnyaschy \& Waldfogel, 2007), which is also the case for Germany (Bünning, 2015; Reimer, 2013, Reimer \& Andernach, 2015).

However, even assuming that the use of parental leave by fathers could increase their investment in infant care beyond leave (O'Brien \& Moss, 2010), there is still shortage of evidence on whether it is the use of leave itself that triggers this effect or rather a particular detail/aspect of the use of parental leave by fathers. Research is needed to examine how fathers' use of parental leave influences gender-specific "care arrangements" (Pfau-Effinger, 2005) and which particular details of parental leave use are relevant for paternal participation in childcare beyond parental leave. 
Until now, some studies aimed at explaining how specific single details of fathers' parental leave take-up relate to their subsequent childcare engagement. As we know from different country contexts, such factors can include the length of paternal parental leave (Almqvist \& Duvander, 2014; Boll, Leppin, Reich, 2014; Haas \& Hwang, 2008; Huerta et al., 2013; Nepomnyaschy \& Waldfogel, 2007), the timing of parental leave (Nepomnyaschy \& Waldfogel, 2007; Rehel 2014) and whether the father is on parental leave alone, i.e. without the partner being at home at the same time (Brandth \& Kvande, 2015; Bünning, 2015; Doucet, 2017; Wall, 2014). Nevertheless, there is a research gap in explaining the relationship between fathers' use of parental leave and their involvement in childcare by comparing the relevance/importance of these details of fathers' parental leave use. Moreover, it is difficult to explain the link between parental leave and childcare, as fathers who take parental leave are likely to be more involved in childcare in general. It is therefore important to investigate the extent to which fathers with and without parental leave differ in their commitment before and after parental leave.

This paper takes the German case as a foundation to review the relationship between fathers' leave-taking details and the time they spend on childcare after parental leave and examines the following questions: (1) What differences in childcare commitment do fathers, according to different aspects of parental leave take-up show compared to fathers who do not use parental leave? (2) Are fathers who take up parental leave, in contrast to fathers who do not use it, more involved in childcare even before parental leave begins?

The analysis is carried out with data from a German panel study (German Socio-Economic Panel). To investigate whether the participation of fathers in childcare in the second and third years after parental leave differs according to the details of parental leave use, we use t-tests. We distinguish between three details of parental leave use: the duration of parental leave, the use of parental leave immediately after the birth of a child and the use of parental leave alone without the partner being on leave at the same time. The question whether fathers who take parental leave spend already more time on childcare before the parental leave uptake and whether fathers' commitment to childcare during parental leave changes is assessed with difference-in-differences analysis.

With this study, we aim to provide a contribution for further analysis of the relationship between details of parental leave and fathers' involvement in childcare, in order to gain further insights into the relevance of "father-sensitive" (O'Brien, 2009) parental leave policy design.

\section{The context: German parental leave legislation}

In 2007, the German government introduced a new law on parental leave. It was designed along the lines of laws on parental leave in the Nordic countries, which aim to improve gender equality and are considered successful. The introduction of new parental leave benefits was linked to three main objectives: increasing female labour market participation, fostering paternal engagement in childcare and increasing birth rates (Reimer, 2013). The advantages of the law for children were hardly discussed. The new 
law did not change the right of working parents to parental leave for three years after the birth of a child, but formulated new rights to financial benefits. Previously, one parent was eligible to receive $€ 300$ per month for two years or $€ 450$ per month for one year. With the new legislation, these parental leave payments changed substantially. Parental leave benefit is now calculated from the individual parent's previous net income and is paid at $65 \%$ of former net earnings ${ }^{3}$ up to a maximum of $€ 1,800$ per month (minimum: $€ 300$ per month). The benefit is available for a maximum period of up to 12 months, with two additional bonus months for the second parent if both parents take at least two months' leave each. The 14 months of paid parental leave can be freely shared between the two parents and taken together or consecutively.

The new German law on paid parental leave is gender-neutral. At the same time, gender equality is to be explicitly promoted, in particular by increasing the involvement of fathers in childcare to enable mothers to participate equally in employment. Two aspects of the 2007 law on paid parental leave are intended as incentives to encourage fathers to take parental leave. The first aspect is a generous wage replacement rate, where the benefit should allow fathers to take parental leave without suffering too great a loss of family income. The second aspect is the introduction of two exclusive "partner months". With their "use-it-or-lose-it" logic, these exclusive rights aim to encourage fathers to take at least two months' paid parental leave (Reimer, 2013). They are often referred to as "daddy-months", which shows that in Germany the mother is still considered the primary carer in the first year of the child's life.

In 2013, one in three fathers took at least part of their parental leave, while almost all women used their leave entitlement. When men take parental leave, they usually take only two months, as implied by the "unwritten norm" (Trappe, 2013) of exclusive partner months and fathers' share of parental leave months in Germany is below 10 per cent (Reimer \& Andernach, 2015; Reimer et al. 2019).

In addition to the aim of the new legislation to promote gender equality by increasing the fathers' parental leave take-up, it was also expected that fathers who took leave would devote more time to childcare after the leave period. Although there are some indications that the use of parental leave by fathers in Germany corresponds positively with their later time for childcare (Bünning, 2015; Reimer \& Andernach, 2015), it is unclear which details of the use of parental leave by fathers are decisive for this relationship and the extent to which the relationship continues beyond the use of parental leave.

\section{Findings from the literature}

Several findings from the international literature provide insights into the relationship between parental leave of fathers and their involvement in childcare. In general, fathers who have taken parental leave are more likely to be involved in childcare after parental

${ }^{3}$ Parents whose previous income was below $€ 1,240$ per month receive payments at higher percentage rates. 
leave than fathers who have not taken parental leave (Bünning, 2015; Pragg \& Knoester, 2017) and to participate in childcare tasks (Haas, 1990; Haas \& Hwang, 2008; Huerta et al., 2013; Seward et al., 2006). However, there are indications that it is not the use of parental leave per se that affects the paternal childcare practices of fathers, but rather certain characteristics of parental leave use. Such details include the duration of parental leave, the timing of parental leave and whether they spend at least part of their parental leave alone.

\section{The length of parental leave of fathers and their subsequent involvement in childcare}

Lamb (1987) once stated that it is unlikely that parental leave alone would have a lasting effect on fathers' behaviour. In the meantime, however, empirical findings suggest that even for short parental leave of fathers there is a positive correlation with later involvement in childcare (e.g. Petts \& Knoester, 2018). Nevertheless, previous research also suggests that fathers with longer parental leave are more involved in childcare than fathers with short parental leave (Haas, 1990; Haas \& Hwang, 2008; Huerta et al., 2013; Nepomnyaschy \& Waldfogel, 2007; Pragg \& Knoester, 2017) and that they tend to take sole responsibility for the child (Haas, 1990; Haas \& Hwang, 2008). Almqvist and Duvander (2014) also showed that fathers with longer parental leave tend to share childcare more equally with their partner compared to fathers with short leave after the leave period.

\section{The point in time of fathers' leave and their subsequent involvement in childcare}

In addition to the duration of fathers' leave, there is also evidence that the timing of fathers' parental leave can have an impact on fathers' participation in childcare beyond parental leave. To the best of our knowledge, there are currently no analyses that have examined the significance of the period of parental leave taken by fathers shortly after the birth of a child for paternal involvement compared to other periods of parental leave. However, there is evidence that fathers who were on parental leave for two or more weeks after the birth of the child are nine months later more involved in childcare than other fathers (Nepomnyaschy \& Waldfogel, 2007). In the later paternal use of parental leave, the dynamics of the gender-specific division of labour in the family could already be determined and thus the role of the father as "helper" could already be defined (ibid.). It is also argued that fathers who take leave shortly after the birth of a child are more likely to exercise parenthood in a way that is more similar to that of mothers (Rehel, 2014). 


\section{Fathers on leave alone and their subsequent involvement in childcare}

The influence of fathers' parental leave alone on their involvement in childcare after leave was considered in several qualitative analyses (e.g. Duvander et al., 2017; Gíslason, 2017; Kvande \& Brandth, 2017; Lammi-Taskula, 2017; Meil et al., 2017; Nakazato, 2017; O’Brien \& Twamley, 2017; Tremblay \& Dodeler, 2017; Valarino, 2017; Wall \& Leitão, 2017). Here, the book by O'Brien and Wall (2017) on fathers' leave alone has to be highlighted, in which this relationship was studied for various European countries. In their conclusion Wall and O'Brien (2017, p. 263) emphasize that "fathers' experiences during paternity leave taken with the mother immediately after the birth of the child are consistently reported as different from those of solo caring during full-time parental leave", with possible long-term consequences for fathers' involvement beyond leave. To what extent this actually is the case, however, still has to be examined with longitudinal data (ibid.). Based on German quantitative longitudinal data, Bünning (2015) was able to confirm a positive correlation between fathers' use of parental leave alone and their subsequent time for childcare. However, there is a gap in research on the extent to which fathers differ in their later childcare engagement according to the characteristics of their use of parental leave. Moreover, still the question remains open whether fathers with take-up of parental leave opposed to fathers without leave use where already more involved in childcare before staying on parental leave.

\section{Theoretical background and hypotheses}

Paternal involvement encompasses three components: (1) time spent in interaction with the child, (2) accessibility (availability) to the child, and (3) taking responsibility, as opposed to merely helping out (Lamb et al., 1987). Both parental leave take-up and time spent on childcare are components of father involvement. They represent different dimensions of paternal care and must therefore be understood differently (Reimer 2017). Two close relationships between these dimensions are discussed in the literature. Firstly, fathers taking parental leave may also be more inclined to engage in childcare afterwards because of their ideas about paternity (e. g. Duvander \& Jans, 2009; Kotsadam $\&$ Finseraas, 2011). This kind of relationship between parental leave and the future time spent on childcare has its origins in fathers' ideas about their role as fathers and includes the implicit idea that these self-concepts are mainly fixed around the time of birth and the early years of children. The second close link between fathers' parental leave and the time they spend on childcare after leave concerns the assumption that fathers' care practices may change as a result of their experience during leave. It is assumed that parental leave can result in a changed self-image as father and that fathers acquire skills as caring fathers during this period (Pragg \& Knoester, 2017). While the former assumption on the relationship between parental leave of fathers and their participation in childcare does not imply changes in childcare practices before and after parental leave, the latter assumption does. However, the intensity of these experiences could vary due to the length 
of time fathers take leave, the time they take it and whether they take parental leave without the mother also being at home at the same time.

We build on two theories to address differences in fathers' involvement in childcare based on the details of their prior parental leave use: Identity theory (Rane \& McBride, 2000) and the undoing gender framework (Deutsch, 2007). Identity theory is used to explain the influence of fathers' parental leave on their later involvement in childcare with changes in their identity hierarchy. The "undoing gender" framework is used to inform assumptions about the relationship between parental leave of fathers and care arrangements in the family.

The identity theory sees the self as a multiplicity of identities that are structured by role relationships and are ordered hierarchically (Rane \& McBride, 2000). Individual behaviour is seen as directly linked to the identity hierarchy of a person (ibid.). Fathers who prioritise their role as fathers should therefore also show a stronger commitment to childcare. This is in line with the findings of Rane and McBride (2000), who point out that the central role of education is strongly linked to the involvement of the father. We assume that, based on their experiences during parental leave, fathers redefine their relative positions regarding their role as breadwinners and as carers, with consequences for their paternal commitment beyond the period of parental leave. Also, during longer parental leave or leave taken alone, fathers' experiences are more likely to lead to a change in their identities as fathers (e.g. Pragg \& Knoester, 2017). Thus, we assume that the effect of parental leave on future engagement in childcare is stronger if fathers' leave periods are longer and that fathers who have been on parental leave alone are more likely to put their role as caring father first than those fathers who were not on leave alone.

Another theory that could explain the influence of fathers' practices and experiences during parental leave on their later participation in childcare is the "undoing gender" framework. Deutsch (2007) introduced the term "undoing gender" to explain the (re-) production of gender differences through social interaction, whereby both persistence and change in gender relations can be the result. The undoing of the gendered division of labour at the interactional level can be promoted through structures aimed at gender equality (Deutsch, 2007), such as gender equal access to parental leave and exclusive rights to parental leave for fathers. During parental leave, fathers have the opportunity to reconstruct traditional gender-specific care arrangements. This can be explained by the fact that they can acquire parental skills by "being on the job" (Lamb et al., 1987). They develop self-confidence as caring fathers and build a closer bond with their child (Rehel, 2014). During shorter parental leave, especially when the mother is also at home to care for the child, the opportunities for fathers to gain skills and confidence as responsible caregivers can be reduced, with consequences for their involvement in childcare.

On the basis of these two theories, particularly fathers who took parental leave alone could be the ones who engage more in childcare after parental leave than before their leave. Wall (2014) states that fathers' leave alone seems to challenge the notion of parental care as a female prerogative. During leave on their own, fathers become the reference person for the child (Valarino, 2017), which changes traditional gender hierarchies in 
childcare and can be the basis for an ongoing dismantling of gendered responsibilities (Doucet, 2017). Leave alone affects how fathers "feel responsible" and "are responsible" (Doucet, 2009). They have the opportunity to become "managers" instead of "assistants" (Doucet, 2006), which facilitates the transition from mother's helper to an equal co-parent (Kvande \& Brandth, 2017). Wall (2014, p. 207) notes that when fathers go on parental leave alone, six key processes can be identified during this time: Fathers who spent some of their leave alone "not only "negotiate" leave and "do" care but also "learn", "bond", "undo gender" and "experience new emotions". They develop a need-oriented care practice and a direct and practical sensitivity to the changing conditions and needs of their infants (Kvande \& Brandth, 2017) and at the same time gain confidence as a caring father (Doucet, 2017; Kvande \& Brandth, 2017; Wall \& Leitão, 2017). Taken together, these findings suggest that when fathers are on leave alone, they are more likely to develop skills as responsible, caring parents, with a corresponding bonding effect (Kvande \& Brandth, 2017; Meil et al., 2017; Wall \& Leitão, 2017).

After these theoretical considerations we put forward the following hypotheses on the differences in fathers' engagement in childcare due to leave characteristics:

H1: German fathers who take longer parental leave are more involved in childcare in the years after parental leave than fathers who take shorter parental leave.

H2: German fathers who go on parental leave shortly after the birth of a child are more involved in childcare in the years following parental leave than fathers on leave at a later date.

H3: German fathers who take care of their children alone during parental leave are more involved in childcare in the years after parental leave than fathers who were at home with their partner during parental leave.

H4: The differences between the time for childcare before and after the leave period are largest for fathers who were on parental leave alone compared to other groups of fathers who were on parental leave.

Based on the assumption that during parental leave fathers experience a shift in their identities as a father and a change in their childcare practises we also put forward the following hypothesis:

H5: Fathers who take parental leave are not more involved in childcare before their parental leave than fathers without parental leave.

\section{Data and methods}

For the empirical analysis of the relationship between the details of parental leave taken by fathers and the time they spend on childcare after the leave period we draw on integrated data from the German Socio-Economic Panel (SOEP), which is a representative longitudinal study of nearly 11,000 private households in Germany, and the additional sample "Families in Germany" (FiD). We examine employed fathers with a child born between 2007 and 2011. 
Methods

We examine our hypotheses by applying two analytical strategies.

t-tests

To investigate whether the participation of fathers in childcare in the second and third years after parental leave differs according to the details of parental leave use (duration, timing and leave alone; hypotheses 1-4), we use t-tests. For all $t$-tests, Levene's test was used to determine whether the assumption of equal variances was fulfilled. If this was not the case, a variation of the t-test was applied instead, considering the unequal variances. The results of these group comparisons are suitable for determining the extent and significance of the differences. However, earlier studies (Reimer \& Andernach, 2015) have shown that the influence of parental leave on paternal childcare disappears in more complex models, as other factors such as fathers' working hours and the partner's employment participation are more important determinants of fathers' time with children. Here, we focus exclusively on the differences in the relationship between the characteristics of parental leave and later childcare, without considering other factors, in order to examine the significance of differences between groups of fathers with different leave details.

\section{UNIANOVA}

With UNIANOVA, we examine whether fathers who take parental leave (alone) spend already more time on childcare before the parental leave uptake and whether fathers' commitment to childcare during parental leave increases (hypothesis 5). The focus is on first-time fathers only to investigate exclusively the childcare time for one child. The dependent variable is fathers' time for childcare, the independent variables are the details of fathers' parental leave use (duration, timing and leave alone) and the time of measurement. This method is suitable to analyse the difference-in-differences (DiD) in a controlled before-and-after study design. The robustness of the results was verified and confirmed with a linear regression model as another method to estimate the difference-in-differences. Here, the information on treatment and measurement time and their interaction terms was applied to evaluate also the significance of the relationship between individual factors (and the interaction term) and the dependent variable.

The treatment is defined as the parental leave behaviour of fathers, and so the treatment group consists of fathers with a certain parental leave detail and the control group consists of fathers without this detail. To assess the difference-in-differences, the time spent on childcare was measured at two different times for each group. For the treatment group, the measurement of time spent by fathers on childcare before treatment was obtained from the information between the birth of the child and the beginning of their parental leave. The post-treatment measurements were obtained from the interview after parental leave. For the control group, these measurements were obtained from 
the first or second year after the birth of a child in order to simulate comparable points in time. For this analysis, these requirements led to the exclusion of fathers who took parental leave immediately after the birth of a child.

The usefulness of controlled before-and-after studies in an ex-post design is limited, as the effect estimate cannot be assigned to the intervention with certainty due to the control group being non-randomized (Grimshaw et al., 2000). Conclusions about a causal relationship with the results are therefore inadmissible. The analysis design is, however, suitable for generating cautious assumptions about hypotheses $4 \mathrm{a}$ and $4 \mathrm{~b}$ and the results may provide a basis for further research.

\section{Variables}

In order to measure the time fathers spend on childcare, we have used the reported time spent on childcare on weekdays. This was collected in the questionnaire with the following question: "How many hours per normal weekday do you spend on childcare? Please enter whole hours only". For the comparisons between fathers on different types of leave, we have used monthly calendar data on the use of paid parental leave by fathers. To assess whether a father took the parental leave alone, the calendar data on parental leave taken were compared with the employment status of his partner in each month. For the t-tests, the sample consists of the information on the fathers' youngest child, born between 2007 and 2011; for the DiD, the database was limited to fathers whose first child was born between 2007 and 2011. The number of cases for the various analyses are shown in Table 1.

Table 1. Number of cases

\begin{tabular}{|l|c|}
\hline \multicolumn{1}{|c|}{ Analysis } & N \\
\hline$t$-tests for the $2^{\text {nd }}$ year after the child was born & 1116 \\
\hline$t$-tests for the $3^{\text {rd }}$ year after the child was born & 798 \\
\hline difference-in-differences & 668 \\
\hline
\end{tabular}

Sources: SOEP (2008-2013), FiD (2010-2013); own calculations.

Results

We first investigate whether there is evidence that the use of parental leave by fathers has generally a positive influence on the time they spend on childcare after parental leave. The comparison of fathers having been on parental leave with fathers without parental leave shows a significant positive relationship between the use of parental leave and the time spent on childcare, both in the second and third year after the birth of the child (Table 2). In the second year, the average difference in childcare time between fathers on and not on parental leave is about 17 minutes per day in the favour of the former. In the third year, the average difference is about 28 minutes per day. 
Table 2. Differences in average childcare hours on weekdays between fathers on/not on parental leave

\begin{tabular}{|l|c|c|c|c|}
\hline & $\begin{array}{c}\text { Some parental } \\
\text { leave }\end{array}$ & $\begin{array}{c}\text { No parental } \\
\text { leave }\end{array}$ & Difference & $\begin{array}{c}\text { Difference } \\
\text { in minutes per day }\end{array}$ \\
\hline $\begin{array}{l}2^{\text {nd }} \text { year after child } \\
\text { was born }\end{array}$ & 2.37 & 2.09 & $0.28^{*}$ & 17 \\
\hline $\begin{array}{l}3^{\text {rd }} \text { year after child } \\
\text { was born }\end{array}$ & 2.60 & 2.13 & $0.47^{* *}$ & 28 \\
\hline
\end{tabular}

Sources: SOEP (2008-2013), FiD (2010-2013); own calculations; ${ }^{* * *} \mathrm{p}<.01,{ }^{* *} \mathrm{p}<.05,{ }^{*} \mathrm{p}<.10$.

In the next step, we investigate whether there are differences in the impact of the details of fathers' parental leave use (duration, timing and leave alone) on their time for childcare after parental leave.

Regarding the length of parental leave taken by fathers (Table 3), we found a positive but weak relationship for the second year after the birth of the child: fathers with more than two months' parental leave spent on average half an hour more on childcare than fathers with only two months' of leave. Thus, there is some support for Hypothesis 1, which states that fathers with longer leave periods after their leave spend more time in childcare than fathers with only two or less months of leave. The relationship is no longer significant for the third year after the birth of the child.

Table 3. Differences in average hours for childcare on weekdays between fathers with two months of parental leave and fathers with more than two months of parental leave ${ }^{4}$

\begin{tabular}{|l|c|c|c|c|}
\hline & $\begin{array}{c}\text { Two months' } \\
\text { parental leave }\end{array}$ & $\begin{array}{c}\text { More than } \\
\text { two months' } \\
\text { parental leave }\end{array}$ & Difference & $\begin{array}{c}\text { Difference } \\
\text { in minutes per day }\end{array}$ \\
\hline $\begin{array}{l}2^{\text {nd }} \text { year after child } \\
\text { was born }\end{array}$ & 2.16 & 2.70 & $0.54^{*}$ & 32 \\
\hline $\begin{array}{l}3^{\text {rd }} \text { year after child } \\
\text { was born }\end{array}$ & 2.30 & 2.96 & 0.66 & - \\
\hline
\end{tabular}

Sources: SOEP (2008-2013), FiD (2010-2013); own calculations; ${ }^{* * *} \mathrm{p}<.01,{ }^{* *} \mathrm{p}<.05,{ }^{*} \mathrm{p}<.10$.

Next, we look at the connection between parental leave taken shortly after the birth of the child and the childcare provided by fathers in subsequent years (Table 4). No significant difference can be observed between fathers who took leave within the first two months after their child was born and those who took their leave at a later date. Thus,

${ }^{4}$ Author's note: in Germany, fathers have to take up two months of parental leave at least to be eligible to the extension of 12 to 14 months per couple. If fathers take parental leave, they take at least two months of leave (either in full- or part-time (see the "German policy" section above). 
for German fathers, early parental leave in the first months after birth does not seem to have a significant impact on their later involvement in childcare and Hypothesis 2 must be rejected.

Table 4. Differences in average hours of childcare on weekdays between fathers on parental leave shortly after birth and fathers on leave at a later date

\begin{tabular}{|l|c|c|c|c|}
\hline & $\begin{array}{c}\text { Leave } \\
\text { within first two } \\
\text { months }\end{array}$ & $\begin{array}{c}\text { No leave } \\
\text { within first two } \\
\text { months }\end{array}$ & Difference & $\begin{array}{c}\text { Difference } \\
\text { in minutes per day }\end{array}$ \\
\hline $\begin{array}{l}2^{\text {nd }} \text { year after child } \\
\text { was born }\end{array}$ & 2.49 & 2.34 & 0.15 & - \\
\hline $\begin{array}{l}3^{\text {rd }} \text { year after child } \\
\text { was born }\end{array}$ & 2.46 & 2.64 & -0.18 & - \\
\hline
\end{tabular}

Sources: SOEP (2008-2013), FiD (2010-2013); own calculations; *** $\mathrm{p}<.01,{ }^{* *} \mathrm{p}<.05,{ }^{*} \mathrm{p}<.10$.

We are now investigating the connection between fathers' parental leave alone and later childcare time (Table 5). Here we find that for the second year after the birth of a child, fathers who have taken at least one month's leave alone spend an average of 49 minutes more per day on childcare than fathers who have spent their entire parental leave with their partner. For the third year after the birth of the child, this average difference even amounts to 76 minutes per day, which suggests a sustainable relationship between parental leave alone and commitment to childcare. This supports Hypothesis 3 , which assumes a significant positive relationship between fathers having been on leave alone and their subsequent involvement in childcare. When comparing the effects of the three parental leave details studied, we can also say that parental leave of fathers is more strongly related to the paternal time spent on childcare in subsequent years than the duration of the leave, which gives support to Hypothesis 4.

Table 5. Differences in the average hours of childcare on a weekday between fathers who took parental leave without their partner and fathers who took all their leave together with their partner

\begin{tabular}{|l|c|c|c|c|}
\hline & $\begin{array}{c}\text { Some parental } \\
\text { leave taken } \\
\text { alone }\end{array}$ & $\begin{array}{c}\text { Joint parental } \\
\text { leave with the } \\
\text { partner }\end{array}$ & Difference & $\begin{array}{c}\text { Difference } \\
\text { in minutes per day }\end{array}$ \\
\hline $\begin{array}{l}2^{\text {nd }} \text { year after child } \\
\text { was born }\end{array}$ & 2.93 & 2.11 & $0.82^{* *}$ & 49 \\
\hline $\begin{array}{l}3^{\text {rd }} \text { year after child } \\
\text { was born }\end{array}$ & 3.37 & 2.10 & $1.27^{* * *}$ & 76 \\
\hline
\end{tabular}

Sources: SOEP (2008-2013), FiD (2010-2013); own calculations; ${ }^{* * *} \mathrm{p}<.01,{ }^{* *} \mathrm{p}<.05,{ }^{*} \mathrm{p}<.10$. 
We re-examine the observed relationship between fathers who were on leave alone and the time they spend on childcare in subsequent years, distinguishing between fathers who were on leave alone for at least one month and those who took all their leave together with their partner, compared with fathers who took no parental leave at all (Table 6). The results will show whether the fathers' leave alone is the main factor explaining the link between parental leave use and later engagement in childcare.

Table 6. Mean hours for childcare on weekdays of fathers who were on parental leave without their partner and fathers who were on leave together with their partner, compared to fathers who did not use the parental leave

\begin{tabular}{|c|c|c|c|c|c|c|}
\hline & $\begin{array}{c}\text { Parental } \\
\text { leave alone }\end{array}$ & $\begin{array}{c}\text { No parental } \\
\text { leave }\end{array}$ & Difference & $\begin{array}{c}\text { Parental } \\
\text { leave with } \\
\text { partner }\end{array}$ & $\begin{array}{c}\text { No parental } \\
\text { leave }\end{array}$ & Difference \\
\hline $2^{\text {nd }}$ year & 2.93 & 2.09 & $0.84^{* * *}$ & 2.11 & 2.09 & 0.02 \\
\hline $3^{\text {rd }}$ year & 3.37 & 2.13 & $1.24^{* * *}$ & 2.10 & 2.13 & -0.03 \\
\hline
\end{tabular}

Sources: SOEP (2008-2013), FiD (2010-2013); own calculations; ${ }^{* * *} \mathrm{p}<.01,{ }^{* *} \mathrm{p}<.05,{ }^{*} \mathrm{p}<.10$.

We see that there is no significant difference in commitment to care between fathers without parental leave and fathers on parental leave together with their partner, neither in the second nor third year after birth of a child. In contrast, we find a clear difference in the time spent on childcare on weekdays between fathers who were alone on parental leave and fathers without parental leave. Fathers on leave alone spend an average of 50 minutes more in childcare in the second year after the birth of a child than fathers without parental leave. In the third year this difference is even greater, averaging 1 hour and 14 minutes. These results suggest that the link between fathers' parental leave and their subsequent engagement in childcare can be explained mainly by the fact that fathers were on leave alone.

In order to examine whether fathers with parental leave use have, on average, spent more time on childcare already before having taken parental leave than fathers without parental leave use (Hypothesis 5), an analysis of the difference-in-differences between the two is now carried out (Figure 1). This analysis provides information on whether first-time fathers with parental leave use tend to be more involved in childcare before taking up the leave. It will also show whether the participation of fathers in childcare after the period of entitlement to parental leave is influenced by experiences during parental leave. If this were the case, the average time for childcare at the measurement point before the holiday period would have to be the same for fathers with and without parental leave use and would only differ after the leave period. The results demonstrate that on average, fathers in both groups spend a similar amount of time on childcare during the working week before taking leave. Taking parental leave changes this similarity. On average, fathers who have taken leave spend more time looking after children after their leave than fathers who have not taken leave. On the other hand, the mean time spent on childcare for 
fathers without parental leave has hardly changed in the meantime. Hypothesis 5 is thus supported and the results suggest that the use of parental leave by (first-time) fathers has a positive impact on the time they spend on childcare the following year.

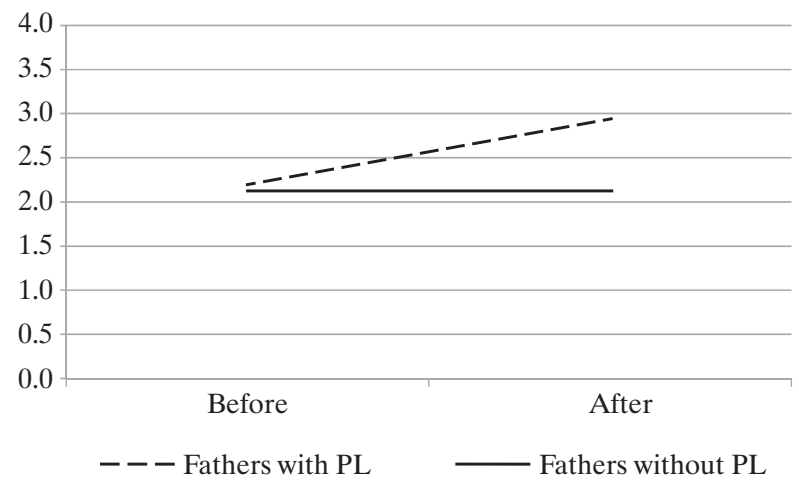

Figure 1. Difference-in-Differences of mean hours for childcare on weekdays for fathers with parental leave and fathers without parental leave before and after leave use/leave entitlement period

Sources: SOEP (2008-2013), FiD (2010-2013); own calculations; difference in differences $p=0.044$.

The next step is to examine the extent to which this difference is greater for fathers on parental leave alone. We examine this question with a further difference-in-difference analysis and compare fathers who took parental leave alone with those who did not take leave (Figure 2). Again, we do not find any major differences between the groups of fathers on parental leave alone and fathers without parental leave, which means that even fathers who take leave alone do, on average, not tend to have more time for childcare before the leave period than fathers without parental leave. Again, it appears that the differences in the time spent on childcare after leave are greater for fathers on leave alone than for all fathers with leave (e.g. Figure 1).

The difference-in-difference analyses do, however, not allow causal conclusions to be drawn, as the required randomization of groups is not given and childcare by fathers is also determined by other factors. This includes in particular the fact that mothers were most likely on parental leave at the first time of the measurement, but may have started working at the second time of the measurement. Also, the availability of full-time daycare facilities might influence fathers' time for childcare. Further analysis is needed to control for these factors. 


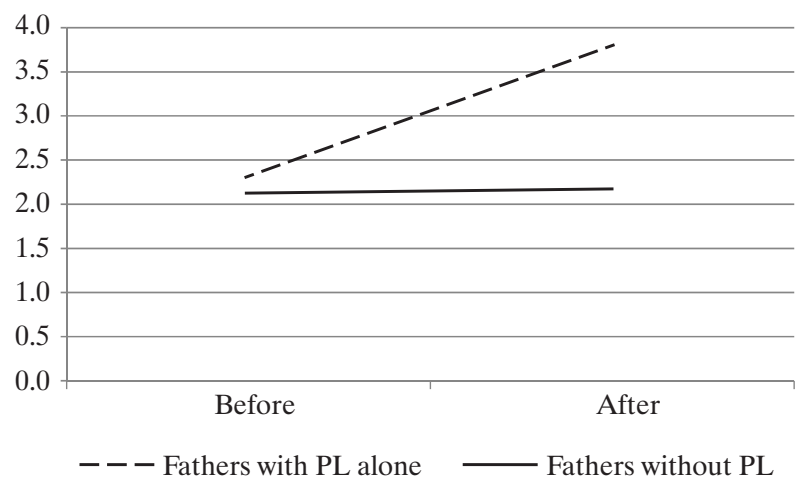

Figure 2. Difference-in-Differences of mean hours for childcare on weekdays for fathers with parental leave alone and fathers without parental leave before and after leave use/leave entitlement period

Sources: SOEP (2008-2013), FiD (2010-2013); own calculations; difference in differences $p=0.002$.

\section{Discussion and conclusion}

In this paper, the relationship between the use of parental leave by German fathers and their subsequent involvement in childcare was examined to fill two partial research gaps in parental leave research. As a first step, the relationship between parental leave and childcare in subsequent years was broken down by three different parental leave details (duration, timing, leave).

Secondly, the study examined the extent to which fathers taking parental leave, as opposed to fathers without leave, are more likely to undertake more childcare even before they take parental leave. We asked two questions: (1) What differences in childcare commitment do fathers with specific parental leave take-up characteristics show compared to fathers without parental leave? (2) Do fathers with parental leave take-up, in contrast to fathers without leave, are more involved in childcare even before parental leave begins?

For fathers with longer parental leave and fathers on leave alone, we found significant differences in childcare engagement compared to fathers without parental leave. We found, however, no systematic differences in childcare engagement after leave between fathers with parental leave immediately after birth and fathers without parental leave. The group of fathers on leave alone showed the most significant difference in commitment to childcare in the years that followed the parental leave. According to our theoretical assumptions, the results suggest that fathers during leave alone or longer parental leave may experience a shift in their father identity from a breadwinner role to a responsible caregiver role by breaking up traditional gender-based care concepts during their leave time. When fathers are on longer leave or leave alone, they experience being "on the job" (Lamb, 1987), which has the potential to change their identity hierarchies and their gender care concepts. Particularly when they are on leave alone, they depart from 
being a "mother's helper" (Rehel, 2014) or "assistants" (Doucet, 2006) and become the "managers" (ibid.) of their child's well-being. The results suggest also that there is a lasting positive relationship to fathers' exclusive entitlements to parental leave for the gender division of childcare beyond leave.

With regard to our second question, we found that before the beginning of the leave period, fathers taking parental leave are on average similar in their commitment to childcare to the group of fathers without parental leave. This also applied to the group of fathers on leave alone. We theorized that during parental leave the identity hierarchies of fathers and their gender-specific care concepts could change, which could lead to greater participation in childcare beyond parental leave. However, the found relationship is likely to be spurious, and since causal assumptions are not appropriate for this analysis design, further analysis with qualitative or quantitative longitudinal data on fathers' childcare commitment and their attitudes towards gender and childcare is needed to further explore these assumptions.

Fathers' engagement in childcare also has to be understood in context. It originates from an interplay of factors on different levels of society (Pfau-Effinger, 2005). Thus, the design of parental leave policy and fathers' parental leave use details may be seen as one of many factors influencing the gender division of care. Particularly mothers' employment participation and fathers' workplaces (e.g. Fagan \& Norman, 2016; Haas \& Hwang, 2008; Hallberg \& Klevmarken, 2003; Kitterød \& Pettersen, 2006; Reimer, 2015, 2019; Smith Koslowski, 2008) are of particular relevance in explaining fathers' engagement in childcare outside of leave. Thus, besides "father-sensitive" parental leave policies (O'Brien, 2009), the mother's equal employment participation, greater equality in pay for women and father-sensitive workplace cultures may be important facilitators for a move towards gender equality in care.

\section{References}

Almqvist, A., \& Duvander, A. (2014). Changes in Gender Equality? Swedish Fathers' Parental Leave, Division of Childcare and Housework. Journal of Family Studies, 20(1), 19-27. https://doi:10.5172/jfs.2014.20.1.19

Boll, C., Leppin, J., \& Reich, N. (2014). Paternal childcare and parental leave policies: Evidence from industrialized countries. Review of Economics of the Household, 12(1), 129-158. https://doi.org/10.1007/s11150-013-9211-z

Brandth, B., \& Kvande, E. (2015). Parental leave and classed fathering practices in Norway. In G. B. Eydal \& T. Rostgaard (eds.), Fatherhood in the Nordic welfare states: Comparing care policies and practice (121-140). Bristol: Policy Press.

Bünning, M. (2015). What Happens after the 'Daddy Months'? Fathers' Involvement in Paid Work, Childcare, and Housework after Taking Parental Leave in Germany. European Sociological Review, 31, 738-748. https://doi.org/10.1093/esr/jcv072

Deutsch, F. (2007). Undoing Gender. Gender \& Society, 21(1), 106-127. https://doi. org $/ 10.1177 / 0891243206293577$ 
Doucet, A. (2006). Do men mother? Fathering, care, and domestic responsibility. University of Toronto Press.

Doucet, A. (2009). Dad and Baby in the First Year: Gendered Responsibilities and Embodiment. The ANNALS of the American Academy of Political and Social Science, 624, 78-98. https://doi.org/10.1177/0002716209334069

Doucet, A. (2017). The Ethics of Care and the Radical Potential of Fathers 'Home Alone on Leave': Care as Practice, Relational Ontology, and Social Justice. In M. O'Brien $\&$ K. Wall (eds.), Comparative Perspectives on Work-Life Balance and Gender Equality. Fathers on Leave Alone. (11-28). Springer.

Duvander, A., \& Jans, A. (2009). Consequences of fathers' parental leave use: Evidence from Sweden. Finnish Yearbook of Population Research, 44, 49-62. http://ojs.tsv.fi/index. php/fyp/article/view/45044

Duvander, A.-Z., Haas, L. \& Thalberg, S. (2017). Fathers on Leave Alone in Sweden: Toward More Equal Parenthood? In M. O'Brien \& K. Wall (eds.), Comparative Perspectives on Work-Life Balance and Gender Equality. Fathers on Leave Alone. (125-145). Springer.

Ehlert, N., \& Rüling, A. (2008). Elterngeld als Teil nachhaltiger Familienpolitik. HUB.

Escot, L., Fernández-Cornejo, J. A., \& Poza, C. (2014). Fathers' Use of Childbirth Leave in Spain. The Effects of the 13-Day Paternity Leave. Population Research Policy Review, 33(3), 419-453. https://doi.org/10.1007/s11113-013-9304-7

Eydal, G. B., \& Gíslason, I. V. (2015). Caring fathers and parental leave in prosperous times and times of crisis: The case of Iceland. In G. B. Eydal \& T. Rostgaard (eds.), Fatherhood in the Nordic welfare states: Comparing care policies and practice. (32-346). Policy Press.

Fagan, C., \& Norman, H. (2016). Which Fathers Are Involved in Caring for Pre-school Age Children in the United Kingdom? A Longitudinal Analysis of the Influence of Work Hours in Employment on Shared Childcare Arrangements in Couple Households. In I. Crespi, \& E. Ruspini (eds.), Balancing Work and Family in a Changing Society: The Fathers' Perspective. (83-98). Palgrave Macmillan.

Gíslason, I. V. (2017). Fathers on Leave Alone in Iceland: Normal Paternal Behaviour? In M. O’Brien \& K. Wall (eds.), Comparative Perspectives on Work-Life Balance and Gender Equality. Fathers on Leave Alone. (147-162). Springer.

Grimshaw, J., Campbell, M., Eccles, M., Steen, N. (2000). Experimental and quasi-experimental designs for evaluating guideline implementation strategies. Family practice, 17(1), 11-6. https://doi.org/10.1093/fampra/17.suppl_1.s11

Haas, L. (1990). Gender Equality and Social Policy. Journal of Family Issues, 11(4), 401-423. https://doi.org/10.1177/019251390011004004

Haas, L., \& Hwang, C. P. (2008). The Impact of Taking Parental Leave on Fathers' Participation in Childcare and Relationships with Children: Lessons from Sweden. Community, Work \& Family, 11(1), 85-104. https://doi.org/10.1080/13668800701785346 
Hallberg, D., \& Klevmarken, A. (2003). Time for children: A study of parent's time allocation, Journal of Population Economics, 16(2), 205-226. https://doi.org/10.1007/ s001480200133

Huerta, M., Adema, W., Baxter, J., Han, W., Lausten, M., Lee, R., \& Waldfogel, J. (2013). Fathers' Leave, Fathers' Involvement and Child Development: Are they Related? Evidence from Four OECD Countries. OECD Social, Employment and Migration Working Papers, 140 . https://doi.org/10.1787/5k4dlw9w6czq-en

Kitterød, R. H., \& Pettersen, S. V. (2006). Making up for mother's employed working hours?: Housework and childcare among Norwegian fathers. Work, Employment \& Society, 20(3), 473-492. https://doi.org/10.1177/0950017006066997

Kotsadam, A., \& Finseraas, H. (2011). The state intervenes in the battle of the sexes: Causal effects of paternity leave. Social Science Research, 40(6), 1611-1622. https:// doi.org/10.1016/j.ssresearch.2011.06.011

Kvande, E., \& Brandth, B. (2017). Fathers on Leave Alone in Norway: Changes and Continuities. In M. O'Brien \& K. Wall (eds.), Comparative Perspectives on Work-Life Balance and Gender Equality. Fathers on Leave Alone. (29-44). Springer.

Lamb, M. E. (1987). Introduction: The emergent American father. In M. E. Lamb (ed.), The father's role: Cross-cultural perspectives. (3-25). Erlbaum.

Lamb, M. E., Pleck, J. H., Charnov, E. L., \& Levine, J. A. (1987). A biosocial perspective on paternal behavior and involvement. In J. B. Lancaster, J. Altman, A. Rossi, $\&$ L. R. Sherrod (eds.), Parenting across the lifespan: Biosocial perspectives. (11-42). Academic.

Lammi-Taskula, J. (2017). Fathers on Leave Alone in Finland: Negotiations and Lived Experiences. In M. O'Brien \& K. Wall (eds.), Comparative Perspectives on Work-Life Balance and Gender Equality. Fathers on Leave Alone. (89-106). Springer.

Meil, G. (2013). European Men's Use of Parental Leave and Their Involvement in Child Care and Housework. Journal of comparative family studies, 44(5), 557-570.

Meil, G., Romero-Balsas, P., \& Rogero-García, J. (2017). Fathers on Leave Alone in Spain: 'Hey, I Want to Be Able to Do It Like That, Too'. In M. O'Brien \& K. Wall (eds.), Comparative Perspectives on Work-Life Balance and Gender Equality. Fathers on Leave Alone. (107-124). Springer.

Nakazato, H. (2017). Fathers on Leave Alone in Japan: The Lived Experiences of the Pioneers. In M. O'Brien \& K. Wall (eds.), Comparative Perspectives on Work-Life Balance and Gender Equality. Fathers on Leave Alone. (231-255). Springer.

Nepomnyaschy, L., \& Waldfogel, J. (2007). Paternity leave and fathers' involvement with their young children: Evidence from the American Ecls-B. Community, Work \& Family, 10(4), 427-453. https://doi.org/10.1080/13668800701575077

O’Brien, M. (2009). Fathers, Parental Leave Policies, and Infant Quality of Life: International Perspectives and Policy Impact. The Annals of the American Academy of Political and Social Science, 624(1), 190-213. https://doi.org/10.1177/0002716209334349 
O'Brien, M. (2013). Fitting fathers into work family policies: International challenges in turbulent times. International Journal of Sociology \& Social Policy, 33, 542-564. https:// doi.org/10.1108/IJSSP-05-2013-0060

O'Brien, M., \& Moss, P. (2010). Fathers, Work and Family Policies in Europe. In M. E. Lamb (Hg.), The Role of the Father in Child Development. (551-577). Wiley.

O'Brien, M. \& Twamley, K. (2017). Fathers Taking Leave Alone in the UK - A Gift Exchange Between Mother and Father? In M. O'Brien \& K. Wall (eds.), Comparative Perspectives on Work-Life Balance and Gender Equality. Fathers on Leave Alone. (163-181). Springer.

O'Brien, M., \& Wall, K. (2017): Comparative Perspectives on Work-Life Balance and Gender Equality. Fathers on Leave Alone. Springer.

Petts, R., \& Knoester, C. (2018). Paternity Leave-Taking and Father Engagement. Journal of marriage and the family, 80(5), 1144-1162. https://doi.org/10.1111/jomf.12494

Pfau-Effinger, B. (2005). Welfare state policies and the development of care arrangements. European Societies, 7(2), 321-347. https://doi.org/10.1080/14616690500083592

Pragg, B., \& Knoester, C. (2017). Parental Leave Use among Disadvantaged Fathers. Journal of Family Issues, 38(8), 1157-1185. https://doi.org/10.1177/0192513X15623585

Rane, T., \& McBride, B. A. (2000). Identity Theory as a Guide to Understanding Fathers' Involvement With Their Children. Journal of Family Issues, 21(3), 347-366. https://doi. org/10.1177/019251300021003004

Rehel, E. M. (2014). When Dad Stays Home Too: Paternity Leave, Gender, and Parenting. Gender \& Society, 28(1), 110-132. https://doi.org/10.1177/089124321350

Reimer, T. (2013). Elterngeld. Springer Fachmedien Wiesbaden. https://doi.org/10.1007/9783-658-01620-3

Reimer, T. (2015). Working time arrangements and family time of fathers: How work organization(s) shape fathers' opportunities to engage in childcare. management revue, 26(3), 227-252. https://doi.org/10.5771/0935-9915-2015-3-227

Reimer, T. (2017). Measuring German Fathers' Involvement in Childcare. Men and Masculinities, 20(5), 588-608. https://doi.org/10.1177/1097184X17728318.3900

Reimer, T. (2019). Why fathers don't take more parental leave in Germany: comparing mechanisms in different work organizations. Community, Work \& Family, 36(3), 1-20. https://doi.org/10.1080/13668803.2019.1608157

Reimer, T., \& Andernach, B. (2015). Aktivierte Väter durch Elterngeld? Eine Untersuchung des Zusammenhangs von väterlicher Elterngeldnutzung und ihren Kinderbetreuungszeiten. In S. Lessenich (ed.), Routinen der Krise - Krise der Routinen. (280-302).

Reimer, T., Erler, D. Schober, D., \& Blum, S. (2019). Germany country note. In A. Koslowski, S. Blum, I. Dobrotic, A. Macht, \& P. Moss (eds.), International Review of Leave Policies and Research. https://www.leavenetwork.org/annual-review-reports/ country-reports/ 
Seward, R. R., Yeatts, D. E., Amin, I., \& DeWitt, A. (2006). Employment Leave and Fathers' Involvement with Children: According to Mothers and Fathers. Men and Masculinities, 8(4), 405-427. https://doi.org/10.1177/1097184X05277689

Smith Koslowski, A. (2008). Who cares? European fathers and the time they spend looking after their children. VDM.

Trappe, H. (2013). Väterzeit - das Elterngeld als Beschleuniger von Gleichstellung? Zeitschrift für Familienforschung, 25(2), 238-264.

Tremblay, D.-G., \& Dodeler, N. L. (2017). Fathers on Leave Alone in Quebec (Canada): The Case of Innovative, Subversive and Activist Fathers. In M. O'Brien \& K. Wall (eds.), Comparative Perspectives on Work-Life Balance and Gender Equality. Fathers on Leave Alone. (69-87). Springer.

Valarino, I. (2017). Fathers on Leave Alone in Switzerland: Agents of Social Change? In M. O’Brien \& K. Wall (eds.), Comparative Perspectives on Work-Life Balance and Gender Equality. Fathers on Leave Alone. (205-230). Springer.

Wall, K. (2014). Fathers on Leave Alone: Does It Make a Difference to Their Lives? Fathering, 12(2), 196-210.

Wall, K., \& O'Brien, M. (2017). Discussion and Conclusions. In M. O'Brien \& K. Wall (eds.), Comparative Perspectives on Work-Life Balance and Gender Equality. Fathers on Leave Alone. (257-266). Springer.

Wall, K., \& Leitão, M. (2017). Fathers on Leave Alone in Portugal: Lived Experiences and Impact of Forerunner Fathers. In M. O’Brien \& K. Wall (eds.), Comparative Perspectives on Work-Life Balance and Gender Equality. Fathers on Leave Alone. (45-67). Springer. 